\title{
Nursery rearing of Thai sarpunti, Barbonymus gonionotus larvae using three different supplementary feeds
}

\author{
A. K. S. Ahammad, M. M. R. Khan, M. A. Hossain ${ }^{1}$ and I. Parvez ${ }^{2}$ \\ Department of Fisheries Biology and Genetics, Bangladesh Agricultural University, Mymensingh-2202, Bangladesh \\ ${ }^{1}$ Department of Biotechnology, Bangladesh Agricultural University, Mymensingh-2202, Bangladesh \\ ${ }^{2}$ Department of Fisheries Biology and Genetics, Hajee Mohammad Danesh Science and Technology University, \\ Dinajpur, Bangladesh
}

\begin{abstract}
Nursery rearing of silver barb, Puntius gonionotus (Bleeker, 1850) larvae was carried out with three different feeding treatments $T_{1}, T_{2}$ and $T_{3}$ having three replications each in nine rectangular glass aquaria $(45 \times 25 \times 24 \mathrm{~cm})$ for a period of 28 days in laboratory condition. Live planktonic feed (5000 cells/L), plankton and rice bran having $14.14 \%$ protein, and plankton and Saudi-Bangla nursery feed having $30.20 \%$ protein were tested as $T_{1}, T_{2}$ and $\mathrm{T}_{3}$, respectively. Three days old larvae of $B$. gonionotus (average length $5.0 \pm 0.15 \mathrm{~mm}$ and weight $7.0 \pm 0.05 \mathrm{mg}$ ) were stocked at a stocking density of 4.1 larvae/L of water in each aquarium. The highest length at harvest $(28.06 \pm 0.38 \mathrm{~mm}$ and weight $135.00 \pm 3.05 \mathrm{mg})$ and also highest SGR $(18.79 \pm 0.80)$ were found in $\mathrm{T}_{3}$ followed by $\mathrm{T}_{2}$ and $\mathrm{T}_{1}$. The survival rate in all the treatments was high (92-90\%) and treatment to treatment variation was not significant $(P<0.05)$. The result implies that the application of supplemental feeds over control in nursery rearing of $B$. gonionotus larvae had positive role. The non-significant growth variation between $T_{2}$ and $T_{3}$ indicate suitability of the use of low protein content supplemental feed in the farmers nursery pond during the nursery rearing of $B$. gonionotus larvae.
\end{abstract}

Keywords: Silver barb, Nursery rearing, Rice bran, Plankton

\section{Introduction}

Barbonymus gonionotus (Bleeker, 1850) commonly known as silver barb, is an exotic fish of Bangladesh belonging to Cyprinidae family. Among all the exotic fish species of Bangladesh, it is considered to be one of the best suitable species for aquaculture due to its better palatability, high yield potential and market demand. Azim et al. (2004) reported that the excreta of silver barb had enriched pond bottom that was partly eaten by common carp and partly acted as a fertilizer, which might have promoted phytoplankton production. The excreta of silver barb is reported to influence the growth of common carp (Phaohorm, 1980; Dev, 1994; Shahabuddin et al., 1994).

Silver barb has become increasingly popular in Bangladesh following its introduction from Thailand, owing to its rapid growth and the fact that it attains marketable size in 3-4 months (Gupta and Rab, 1994; Islam et al., 1998), has a bright silvery appearance, and good taste. It has occupied a prime position in aquaculture scenario of Bangladesh within a short time after introduction. Besides polyculture, it is also used in monoculture systems in Bangladesh. It was observed that an addition of 2,500 fingerling/ha of silver barb in polyculture has increased the growth of common carp and overall fish production (Haque et al., 1998). Azim et al. (1998) reported that duckweed can be used as an effective supplementary feed in the polyculture of silver barb stocked at the rate of 5,000 fingerlings/ha in four species polyculture system. Wahab et al. (2001) reported that addition of duckweed and supplementary feed (rice bran and oil cake) may compensate any inter-specific and intra-specific dietary competition with the stocking of Thai silver barb at the rate of 6000 fingerling /ha in the polyculture system. Similar works have been conducted on production of Thai sarpunti in earthen pond in Bangladesh (Kohinoor et al., 1993; Hossain et al., 1998).

Silver barb is a herbivorous species and feeds mainly on aquatic plants, soft grasses and plankton (Phaohorm, 1980; Haroon and Pittman, 1997). Silver barb has been screened as candidate species for rice-cum-fish culture, and a considerable amount of work on their food and feeding habits, and growth performance in rice fields has been reported (Miah et al., 1994; Haroon and Pittman 1997; Vormant et al., 2001). It was found that silver barb ingested more crustaceans during the first sampling day than in the last sampling day (Azim et al., 2004). Mohanta et al. (2007) reported that dietary protein can be reduced from 300 to $350 \mathrm{~g} / \mathrm{kg}$ to 200 and $250 \mathrm{~g} / \mathrm{kg}$ diet by increasing carbohydrate from 260 to $340 \mathrm{~g} / \mathrm{kg}$ diet without sacrificing the growth that was undertaken to examine the protein-sparing effect of carbohydrate in the diets for silver barb fry. 
Many commercial fish feeds viz. Saudi-Bangla nursery feed (Saudi-Bangla Fish Feed Bangladesh Ltd.), Quality nursery feed (Quality Fish Feed Bangladesh Ltd.) and Aftab nursery feed (Aftab Feed Bangladesh Ltd.) are commonly used for mass production of $B$. gonionotus seeds. Among these, Saudi-Bangla nursery feed for carps and catfishes has become popular because of its high protein content $(30 \%)$ and also fish can take it easily due to its high compactness. The production of good quality seed depends on adequate supply of nutritional requirements as well as on the range of their tolerance to the different environmental factors. The effect of various parameters such as appropriate feed, feeding rate, feeding frequency etc. are to be properly understood and managed accordingly for increasing growth and survival of the fry. Fish farmers of the country are using high protein content artificial feed for the nursery rearing of this species in their nursery ponds which is not cost effective. So, suitable feed for nursery rearing needs to be identified and finally ensured. In view of the above, an experiment was conducted to develop suitable nursery rearing technique of this species by observing the effects of different feeds on the growth and survival of $B$. gonionotus larvae.

\title{
Materials and Methods
}

The experiment was conducted in nine rectangular glass aquaria $(45 \times 25 \times 24 \mathrm{~cm})$ each containing 17 $L$ of deep tube-well water in the Wet Laboratory of Bangladesh Agricultural University, Mymensingh for a period of 28 days from 22 April to 13 May, 2007. The experiment was designed with 3 treatments $\left(T_{1}, T_{2}\right.$ and $\left.T_{3}\right)$ having 3 replications $\left(R_{1}, R_{2}\right.$ and $\left.R_{3}\right)$ each. Three days old larvae (average length $5.0 \pm 0.15 \mathrm{~mm}$ and weight $7.0 \pm 0.05 \mathrm{mg}$ ) of $B$. gonionotus collected from Brahmaputra Fish Seed Complex, Shombhuganj, Mymensingh were stocked in each aquarium at a stocking density of 4.1 larvae/L of water i.e. 70 larvae per aquarium and was reared for 28 days. Half of the water of each aquarium was exchanged by fresh deep tube-well water once a day to avoid water quality deterioration due to food wastage. The faecal out-put and wastage of feed were removed from the aquarium by siphoning. Aeration was provided to each aquarium for $22 \mathrm{~h}$ everyday from air blowers and was stopped for one hour each time during feed supply. The ingredients used for the formulation of three different feeds for $T_{1}, T_{2}$ and $T_{3}$ are shown in Table 1. Proximate composition of rice bran and Saudi-Bangla nursery feed as analyzed is presented in Table 2. Only plankton at the rate of approximately 5000 cells/L of water was provided in $T_{1}$. In addition to plankton, rice bran and SaudiBangla nursey feed at the rate of $3 \%$ of body weight of stocked larvae were also provided for $T_{2}$ and $T_{3}$, respectively. The daily ration was given twice a day (0900 and $1600 \mathrm{~h}$ ). For plankton study, five liters of water samples were collected every week from each aquarium and then passed through plankton net of 55 blotting silk of $100 \mu \mathrm{m}$ mesh size. The collected samples were concentrated to a volume of $40 \mathrm{ml}$ and preserved in plastic vials with $5 \%$ formalin for further analysis. From the concentrated volume of plankton samples, $1 \mathrm{ml}$ was taken by a dropper and then put on the SedwichRafter counting cell. The counting chamber was covered with a cover slip so as to eliminate the air bubbles. Then Sedwich-Rafter counting cell was placed under a compound microscope (Clesceri et al., 1989). Calculation of the abundance of plankton was done using the following formula (Stirling, 1985):

\author{
$\mathrm{N}=(\mathrm{A} \times 100 \times \mathrm{C}) /(\mathrm{V} \times \mathrm{F} \times \mathrm{L})$ \\ Where, \\ $\mathrm{N}=$ No. of plankton cells or units per liter of original water \\ $A=$ Total no. of plankton counted \\ $\mathrm{C}=$ Volume of concentrate of the sample in $\mathrm{ml}$ \\ $\mathrm{V}=$ Volume of field in cubic $\mathrm{mm}$ \\ $\mathrm{F}=$ Number of fields counted \\ $\mathrm{L}=$ Volume of original water in liter
}


Table 1. The ingredients used for the formulation of three different experimental diets for $B$. gonionotus larval rearing

\begin{tabular}{|c|c|c|c|}
\hline Ingredient & $T_{1}$ & $T_{2}$ & $T_{3}$ \\
\hline $\begin{array}{c}\text { 1. Plankton } \\
\text { Phytoplankton } \\
\text { - Bacilariophyceae } \\
\text { - Chlorophyceae } \\
\text { - } \text { Rhodophyceae } \\
\text { Cyanophycea } \\
\text { Zooplankton } \\
\text { - Copepopoda } \\
\text { - Rotifera } \\
\text { - Cladoceran } \\
\text { - Arthropoda }\end{array}$ & Present & Present & Present \\
\hline 2. Rice bran & Absent & Present & Absent \\
\hline 3. Saudi-Bangla nursery feed & Absent & Absent & Present \\
\hline
\end{tabular}

Table 2. Proximate composition (\%) of rice bran and Saudi-Bangla nursery feed used for $B$. gonionotus larval rearing

\begin{tabular}{|c|c|c|c|c|c|c|}
\hline \multirow{2}{*}{ Supplemental feed } & \multicolumn{6}{|c|}{ Parameters } \\
\cline { 2 - 8 } & $\begin{array}{c}\text { Dry } \\
\text { matter }\end{array}$ & $\begin{array}{c}\text { Crude } \\
\text { protein }\end{array}$ & $\begin{array}{c}\text { Ether } \\
\text { extract }\end{array}$ & $\begin{array}{c}\text { Crude } \\
\text { fibre }\end{array}$ & NFE $^{1}$ & \multirow{2}{*}{ Ash $^{2}$} \\
\hline Rice bran & 83.38 & 14.14 & 18.15 & 9.44 & 49.49 & 8.33 \\
\hline Saudi-Bangla nursery feed & 89.96 & 30.20 & 11.60 & 9.60 & 25.90 & 22.68 \\
\hline
\end{tabular}

${ }^{1}$ Nitrogen free extract (NFE) was calculated as 100-\% (moisture+ crude protein+ crude fiber)

The plankton was identified with the aid of standard keys (Prescott, 1962; Needham and Needham, 1962; Bellinger, 1992). Proximate composition of the feed ingredient i.e. estimation of protein, lipid, ether extract, crude fiber, NFE and ash were done by following the standard method (AOAC, 1980) (Table 2). The proximate composition of plankton used in $T_{1}, T_{2}$ and $T_{3}$ were not analyzed. The fish were sampled at weekly interval to determine the increase in length and weight. Sampling was done in the early morning when the fish stomach was almost empty to avoid the biasness of weight due to the presence of excessive feed. Ten (10) fish were randomly collected from each aquariam. The weight (mg) was taken by an analytical balance (College B204S, Switzerland) and the length ( $\mathrm{mm}$ ) by placing the larvae on a petri dish on a $1 \mathrm{~mm}$ graph paper. The specific growth rate was calculated as the percentage of increase of body weight per day over given time interval by the following equation (Ricker, 1997):

Specific growth rate $(\mathrm{SGR})=\left(\mathrm{LnW}_{2}-\mathrm{LnW}_{1}\right) /\left(\mathrm{T}_{2}-\mathrm{T}_{1}\right) \times 100$

Where,

$\mathrm{W}_{2}=$ final live body weight $(\mathrm{g})$ at time $\mathrm{T}_{2}$

$\mathrm{W}_{1}=$ final live body weight $(\mathrm{g})$ at time $\mathrm{T}_{1}$

The experiment was terminated on the $28^{\text {th }}$ day and the fry were harvested from the aquarium and their final length and weight were measured. The survival rate was estimated as follows:

Survival rate $(\mathrm{SR} \%)=($ No. of fish harvested $\times 100) /$ Initial no. of fish

The physico-chemical parameters such as water temperature, dissolved oxygen (DO), free carbon dioxide $\left(\mathrm{CO}_{2}\right)$, total alkalinity (carbonate and bi-carbonate), $\mathrm{pH}$ and ammonia-nitrogen were measured with the help of Aqua Mate Water Testing Kit (Model WAKQ-1A).

The variation in length gain (mm), weight gain (g), specific growth rate (SGR) and survival rate of the larvae under different treatments were tested using one way analysis of variance (ANOVA). Significant results $(P<0.05)$ were further tested using DMRT to identify significant differences among means. The statistical analysis was performed with the aid of the computer software MSTATC program. 


\section{Results and Discussion}

The highest gain in length at harvest $(28.06 \pm 0.38 \mathrm{~mm})$ and in weight $(135.00 \pm 3.05 \mathrm{mg})$ was observed in $T_{3}$ and followed by $T_{2}$ and $T_{1}$. The growth of fish as obtained from $T_{2}$ and $T_{3}$ was significantly $(P<0.05)$ different from $T_{1}$, though there were no significant variation in growth between $T_{2}$ and $T_{3}$ (Table 4). This was probably due to variation in the quality of feed administered to different treatments.

Table 3. Average water quality parameters of ponds belonging to different treatments during the study period

\begin{tabular}{|c|c|c|c|c|c|}
\hline Treatment & Temperature $\left({ }^{\circ} \mathrm{C}\right)$ & $\mathrm{P}^{\mathrm{H}}$ & $\begin{array}{c}\text { Dissolve oxygen } \\
(\mathrm{DO})(\mathrm{mg} / \mathrm{L})\end{array}$ & $\begin{array}{c}\text { Total alkalinity } \\
(\mathrm{mg} / \mathrm{L})\end{array}$ & $\begin{array}{c}\text { Ammonia- nitrogen } \\
(\mathrm{mg} / \mathrm{L})\end{array}$ \\
\hline $\mathrm{T}_{1}$ & 27.5 & 8.9 & 5.70 & 68 & 0.27 \\
\hline $\mathrm{T}_{2}$ & 26.8 & 8.5 & 5.75 & 75 & 0.25 \\
\hline $\mathrm{T}_{3}$ & 27.0 & 8.8 & 5.80 & 80 & 0.34 \\
\hline
\end{tabular}

Table 4. Growth parameters and survival of Thai sarpunti, P. gonionotus larvae after 28 days of rearing

\begin{tabular}{|c|c|c|c|c|c|c|}
\hline \multirow{2}{*}{ Treatment } & \multicolumn{2}{|c|}{ Initial size } & \multicolumn{2}{c|}{ Size at harvest } & \multirow{2}{*}{ SGR (\% day) } & \multirow{2}{*}{ Survival rate (\%) } \\
\cline { 2 - 5 } & length $(\mathrm{mm})$ & Weight $(\mathrm{mg})$ & Length $(\mathrm{mm})$ & Weight $(\mathrm{mg})$ & & \\
\hline $\mathrm{T}_{1}$ & $5.0 \pm 0.15$ & $7.0 \pm 0.05$ & $23.16 \pm 0.37^{\mathrm{a}}$ & $88.66 \pm 1.85^{\mathrm{a}}$ & $17.28 \pm 0.07^{\mathrm{a}}$ & $92.36 \pm 1.25^{\mathrm{a}}$ \\
\hline $\mathrm{T}_{2}$ & $5.0 \pm 0.15$ & $7.0 \pm 0.05$ & $27.26 \pm 0.49^{\mathrm{b}}$ & $126.66 \pm 7.26^{\mathrm{b}}$ & $18.55 \pm 0.20^{\mathrm{b}}$ & $90.13 \pm 0.69^{\mathrm{a}}$ \\
\hline $\mathrm{T}_{3}$ & $5.0 \pm 0.15$ & $7.0 \pm 0.05$ & $28.06 \pm 0.38^{\mathrm{b}}$ & $135.00 \pm 3.05^{\mathrm{b}}$ & $18.79 \pm 0.80^{\mathrm{b}}$ & $90.60 \pm 0.58^{\mathrm{a}}$ \\
\hline
\end{tabular}

(Average $\pm \mathrm{SE})$; values of the parameter in each column with different subscripts $(a, b)$ differ significantly $(P<0.05)$.

Guerrero (1976) reported that weight of fish stocked at 10,000/ha with supplemental feeding of rice bran was significantly greater than that of control. Yakupitiage et al. (1991) also reported that rice bran (crude protein 13.3\%) fed at $1 \%$ body weight per day significantly improved the fish growth in duckfish integrated system. Santiago et al. (1989) also reported that a combination of natural and artificial feed increased the growth rates in milk fish. Kohinoor et al. (1993) reported that feeding with rice bran gave significantly better production of $B$. gonionotus $(2384 \mathrm{~kg} / \mathrm{ha} / 6$ months) than that with only fertilization $(2128 \mathrm{~kg} / \mathrm{ha} / 6$ months) treatments.

The highest SGR $(18.79 \pm 0.08)$ was also observed in $T_{3}$ and followed by $T_{2}$ and $T_{1}(18.55 \pm 0.20$ and $17.28 \pm 0.07$, respectively). The SGR values of $T_{3}$ and $T_{2}$ were found to differ significantly from that of $T_{1}$ but there was no significant variation in SGR in values of $T_{1}$ and $T_{3}$. As $B$. gonionotus is a plankton feeder, the regular supply of plankton contributed to the growth and nutrition in all the three treatments, simultaneously regular supply of supplementary feed in $T_{3}$ and $T_{2}$ was probably responsible for the additional growth in those treatments. Wee and Ngamsnal (1978) obtained much lower SGR values (1.27-1.85) in P. gonionotus fed with varying dietary protein levels (15-55) under laboratory condition. The values obtained in the present study were much higher than that reported by the above authors. This may be due to supply of live feed with supplementary feed in the present experiment.

In case of physicochemical parameter no marked difference were observed during the experimental period. The ranges of water quality parameters as recorded from the aquaria belonging to different treatments during the study period were: temperature $27-27.5^{\circ} \mathrm{C}, \mathrm{pH} 8.5-8.9, \mathrm{DO} 5.7-5.8 \mathrm{mg} / \mathrm{L}$ and total alkalinity $68-80 \mathrm{ppm}(\mathrm{mg} / \mathrm{L})$ and the ammonia-nitrogen from $0.25-0.34 \mathrm{ppm}$ (Table 3 ). No free $\mathrm{CO}_{2}$ were detected in any aquarium during the experimental period. According to Jhingran (1983) the values of all these parameters were found to be within suitable range for fish farming. Rahman et al. (1982) recorded, $26-32.2^{\circ} \mathrm{C}$ water temperature, DO values of $0.48-8.60 \mathrm{mg} / \mathrm{L}$, total alkalinity $22-90$ $\mathrm{mg} / \mathrm{L}$ for the experimental ponds. Lakshmanan et al. (1971) made a fortnightly observation on water quality parameters in polycutlure of Indian major carps for one year and recorded $\mathrm{pH}$ value of 6.0-9.3 and total alkalinity of $19.4-78.2 \mathrm{mg} / \mathrm{L}$. These values are similar to those as obtained in the present study. 
The highest survival rate was observed in $T_{1}(92 \%)$ followed by $T_{2}$ and $T_{3}(90 \%$ and $90 \%$, respectively) but there were no significant variation $(P>0.05)$ in survival rate of $B$. gonionotus among the treatments. Continuous aeration and regular siphoning off of excess feed and fish excreta and water exchange etc. minimized deterioration of water qualities probably resulted in survival rate (9092\%). Hossain et al. (1998) found $84 \%$ survival rate in earthen pond. Yakapitiyage et al. (1991) reported that survival rate of Thai sarpunti was (47-92\%) with supplementary feeding of fish in duckfish integrated system. Generally it is accepted that growth of the fish has an inverse relationship with the stocking density as a result of the space-limiting effects that operate on the population (Johnson, 1965; Rahman et al., 2002) reported high survival rate of $O$. pabda at a density of 4 larvae/L).

Supplemental feeding is the single largest recurring cost in intensive and semi-intensive fish culture system. It forms approximately half of the total fish farming cost (Segal and Toor, 1991). It is, there fore, important to the low income farmers to utilize their investments in feed as minimum as possible.

The results of the present study clearly demonstrated that the use of low cost supplemental feed has significant role in promoting the growth of $B$. gonionotus larvae. So, it may be concluded that the use of low cost supplemental feed (rice bran only) with regular fertilization is the most cost effective method for the rearing of $B$. gonionotus larvae in farmer's nursery ponds in Bangladesh.

\section{References}

AOAC.1980. Official Methods of Analysis. W. Horwitz (ed.). Association of Official Analytical Chemists, 13th edition. Washington, D.C. 1018 pp.

Azim, M.E., Wahab, M.A., Kamal, A.H.M. and Ahmed, Z.F. 2004. Feeding relation of Silver barb Barbodes gonionotus (Bleeker) with Indian major and common carp and its effects on fish production in a Polyculture System. J. World Aq. Soc., 35(1): 100-108.

Azim, M.E., Wahab, M.A., Hoque, M.M., Wahid, M.I. and Haq, M.S. 1998. Suitability of duckweed (Lemna sp.) as a dietary supplement in four species polyculture. Progress. Agric., 9 (1\&2): 263-269.

Bellinger, R.J.H, 1992. On the dynamics of exploited fish populations. Fish Invest. London. Ser. II, 19: 533 pp.

Bleeker. 1850. Nomenclature of the genera *Puntius, Cyclocheilichthys, Rasbora* and ${ }^{*}$ Chonerhinos* (Teleostei: Cyprinidae and Tetraodontidae), with comments on the definition of the first reviser. Raffles Bull. Zool. p. 591-600

Clesceri, L.S., Greenberg, A.E. and Trussel, R.R. 1989. Standard methods of the Examination of Water and Wastewater (17th ed.). American Public Health Association, American Water works Association and Water Pollution Control Federation, 1015 Washington D. C., USA 20036. p. 10-203.

Dev, B.C. 1994. Food selection and electivity indices of Thai barb Puntius gonionotus in extensively managed, rain-fed ponds in Bangladesh. Master's Thesis. Deparment of Aquaculture and Management, Bangladesh Agricultural University, Mymensingh, Bangladesh. 43 pp.

Guerrero, R.D. 1976. Culture of Tilapia nilotica at two densities with fertilization and supplemental feeding. Fish. Res. J. Philipp., 1 (1): 39-43.

Gupta, M.V. and Rab, M.A. 1994. Adoption and economics of silver barb (Puntius gonionotus) culture in seasonal waters in Bangladesh. ICLARM technical paper no. 41. International Centre for Living Aquatic Resources Management, Manila, Philippines. p. 34-56.

Haque, S.M., Wahab, M.A., Wahid, M.I. and Haq, M.S. 1998. Impact of Thai silver barb (Puntius gonionotus Bleeker) inclusion of carp polyculture in pond culture system. Bangladesh J. Fish. Res., 2(1): 15-22.

Haroon, A.K.Y. and Pittman, K.A. 1997. Rice-fish culture: feeding, growth and yield of two size classes of Puntius gonionotus Bleeker and Oreochromis spp. in Bangladesh. Aquaculture, 154: 261-281.

Hossain, M.A., Azad Shah, A.K.H., Rahmatullah, S.M. and Sarker, M.S.A. 1998. Effect of suppplementary feeding methods on the growht of Thai sharpunti, Puntius gonionotus (Bleeker) in earthen mini ponds. Bangladesh J. Fish., 21 (1): 99103.

Islam, M.S., Azim, M.E., Rahman, M.M. and Mazid, M.A. 1998. Culture prospects of sharpunti (Puntius gonionotus Bleeker) and common carp (Cyprinus carpio Linnaeus) in backyard ditches at farmer level. Progress. Agric., 8(1-2): 191-194.

Jhingran, V.G. 1983. Fish and Fisheries of India. Hindustan Publishing Corporation. Delhi. 666 pp.

Johnson, W.E. 1965. On mechanism of self regulation of population abundance in Oncorhynchus nerka. Mitt. Int. Verein. Theor. Angew., Limnol., 13: 66-87.

Kohinoor, A.H.M., Akhteruzzaman, M. and Saha, M.S. 1993. Production of Puntius gonionotus (Bleeker) in ponds. Bangladesh J. Zool., 21 (2): 77-83. 
Lakshmanan, M.A.V., Sukumaran, K.K., Murty, D.S., Chakraborty, D.P. and Philipose, M.T. 1971. Preliminary observation on intensive fish farming in freshwater ponds by the composite culture of Indian and exotic species. J. Inland Fish. Soc. India, 2: 1-21.

Miah, M.N.I., Ali, M.H. and Ahmed, N.U. 1994. Mono and polyculture of silver barb (Puntius gonionotus) in deepwater rice systems in Bangladesh. NAGA, 17(3):26-27.

Mohanta, K.N., Mohanty, S.N. and Jena, J.K. 2007. Protein-sparing effect of carbohydrate in silver barb, Puntius gonionotus fry. Central Institute of Freshwater Aquqculture, Bhubaneswar, Orissa, India. 46 pp.

Needham, J.G. and Needham, P.R. 1962. A guide to the study of fresh water biology, fifth edition. Holden Day Inc., Sun Francisco, California, USA. 76 pp.

Phaohorm, S. 1980. The study of biology, feeding and growth of Puntius gonionotus. Annual report, Department of Fisheries, Bangkok, Thailand. 23 pp.

Prescott, G.W. 1962. Algae of the Western Great Lakes area. Wn. C. Brawn Co. Inc., Dubuque, Lowa, USA. 41 pp.

Rahman, M. M., Mollah, M.F.A., Islam, M.M. and Datta, S. 2002. Effects of stocking density and feed quality on the growth and survival of the freshwater catfish (Ompok pabda Hamilton) larvae. Bangladesh J. Fish, 25 (1-2): 99-106.

Rahman, M.S., Chowdhury, M.Y., Haque, A.K.M.A. and Haq, M.S. 1982. Limnological studies of four ponds. Bangladesh J. Fish., 2-5 (1-2): 25-35.

Ricker, W.E. 1997. Growth rates and models. In: Fish Physiology (Hoar, W.S. \& Brett, P.J. eds). Vol.8.Academic press, New York, p. 677-743.

Santiago, C.B., Pantastico, J.B., Baldia, S.F. and Reyes, O.S. 1989. Milkfish (Chanos chanos) fingerling production in freshwater ponds with the use of natural and artificial feeds. Aquaculture, 77: 307-318.

Segal, H.S and Toor, H.S. 1991. Comparison of feeding strategies for common carp based on biomass and biomass pond interactions. In: S. S. De Silva, ed. Fish Nutrition Research in Asia. Proceeding of the Fourth Asian Fish Nutrition workshop. Asian Fish. Soc. Spec. Publ., 5: 181-192.

Shahabuddin, M., Miah, M.S. and Alam, M.S. 1994. Study on production optimization through polyculture of indigenous and exotic carps. Bangladesh J. Train. Dev, 7(2): 67-72.

Stirling, H.P. 1985. Chemical and bioliogical methods of water analysis for Aquaculturists. Institute of Aquaculture, University of Sitri ing, Scottland. $119 \mathrm{pp}$.

Vormant, N., Chau, N.T. and Levier, F.M. 2001. The effect of rice seeding rate and fish stocking on the floodwater ecology of the rice field in direct-seeded, concurrent rice-fish system. Hydrobiol., 445(1-3):151-164.

Wahab, M.A., Azim, M.E., Mahmud, A.A., Kohinoor, A.H.M. and Haque, M.M. 2001. Optimisation of stocking density of Thai silver barb (Barbodes gonionotus Bleeker) in the duckweed-fed four species polyculture system. Bangladesh J. Fish. Res., 5(I): 13-21.

Wee, K.L and Ngamsnal, D. 1978. Production of Puntius gonionotus (Bleeker) in ponds. Indian J. Fish., 21(2): 77-83.

Yakupitiyage, A., Edwards, P. and Wee, K.L. 1991. Supplementary feeding of fish in a duck-fish integrated system. 1. The effect of rice bran. In: S. S. De Silva (ed.) Fish nutrition research in Asia. Proceedings of the Forth Asian Fish Nutrition Workshop. Asian Fish Soc. Spec. Publ., 5: 143-157. 